\title{
The Minority Languages Dilemmas in Turkey: A Critical Approach to an Emerging Literature
}

\author{
Burhan Ozfidan (Corresponding author) \\ Department of Teaching, Learning and Culture \\ Texas A\&M University, TX, USA \\ E-mail: b.ozfidan@tamu.edu \\ Lynn M. Burlbaw \\ Department of Teaching, Learning and Culture \\ Texas A\&M University, TX, USA \\ E-mail: burlbaw@tamu.edu \\ Hasan Aydin \\ Department of Curriculum, Instruction and Culture \\ Florida Gulf Coast University, FL, USA \\ E-mail: aydinhasan04@gmail.com
}

Received: July 3, 2016 Accepted: August 24, 2017 Published: January 6, 2018

doi:10.5296/jei.v4i1.11498 URL: https://doi.org/10.5296/jei.v4i1.11498 


\section{Abstract}

Turkey comprises many ethnic groups other than Turks including, but not limited to, Armenians, Assyrians, Alevi, Arabs, Circassians, Greeks, Kurds, Laz, and Zaza. These groups are ethnically different from Turks and were incorporated into the Ottoman Empire's eastern provinces with de facto autonomy. The main objective of this study is to illustrate the need for a language curriculum and identify the obstacles that minority groups encountered in Turkey. This study examines three large communities: Arabs, Kurds, and Laz. The results indicate that minority people in Turkey who had poor Turkish language education were unable to learn their mother tongue within the formal educational settings from the foundation of the republic until 2012. Some of the ethnic groups' languages, such as Laz, Kurdish, and Arabic, were started at schools as elective courses, but few, if any, textbooks written in these languages exist.

Keywords: Turkey, Language, Minority groups

\section{Introduction}

Turkey comprises many ethnic groups other than Turks including, but not limited to, Armenians, Assyrians, Alevi, Arabs, Circassians, Greeks, Kurds, Laz, and Zaza. Some of the ethnic groups' languages, such as Laz, Kurdish, and Arabic, were started at schools as elective courses, but few, if any, textbooks written in these languages exist (Kaya, 2015). Even textbooks that exist do not mention any of these minority groups; therefore, the existing materials do not reflect the presence of social diversity in Turkey (Kyriakou \& Kaya, 2011). Teaching of any other language than Turkish in the formal education system was banned with a legislation called the Act of Unification of Education "Tevhid-i Tedrisat Kanunu" in 1924.

The Turkish language has had a close relationship with many other different languages throughout its history, as Turkism continually strengthened and developed during the rise of the Ottoman Empire. At its high point, the use of the Turkish language stretched from Asia to Europe and spread out over a large geographic territory (Demirekin \& Evat, 2013). According to this legislation, "No language other than Turkish shall be taught as a mother tongue to Turkish citizens at any institution of education. Foreign languages to be taught in institutions of education and the rules to be followed by schools conducting education in a foreign language shall be determined by law. The provisions of international treaties are reserved" (National Legislative Bodies, 2016, p.132). This study examines three large communities: Arabs, Kurds, and Laz.

\section{Historical Background of Arabic Language in Turkey}

Arabic is a language that has interacted with Turkish throughout much of its history. The Arabic language has received important attention in explaining the feelings of identity among Arabic-speaking societies (Hourani, 1970). Arabic, among the members of the Arab population, is a factor, which helps to construct a sense of personality. Arabs have a close relationship with their language because they consider Arabic as an integral part of their identity. Because it is the language of Islam, they are more careful about preserving their language than many ethnic groups in the world (Hourani, 1970). 


\subsection{From Ottoman Empire to 1923}

Many ancient civilizations were hosted in Anatolia, the land of Turkey. The Turkish people in the $10^{\text {th }}$ century immigrated to Anatolia once the Oghuz union of Turkish tribes from central Asia gave rise to the house of the Ottoman Empire and moved to Asia Minor. Turks, who gained their strength from the military, began expanding further in Anatolia under the leadership of Seljuk family. In the $11^{\text {th }}$ century, Tughril Beg, a member of the Seljuk family founded the Turko-Persian Seljuk Empire and spread Islam along with his rule. Later, the Ottoman Empire (1299-1923) consolidated the various smaller kingdoms under its rule and conquered many lands, with the Empire ultimately covering the Middle East, Central and East Europe, and North Africa (Itzkowitz, 1972).

The Turks adopted Islam, and, while expanding to the West, brought Islam and Arabic into their newly acquired territories. Arabic was carried along with this expansion because Arabic was the language of the Prophet (PBUH) as used in the Holy Quran. Along with Arabic, Turkish, and Persian were used in the Seljuk Empire (1037-1194), which was a Sunni Muslim Empire. Although the Empire used Persian as its official language, Arabic was used for religious purposes.

The Ottoman Empire, which lasted more than 600 years, brought also along with it an educational system, which was a continued and improved version of that of the Seljuk state (Gokce \& Oguz, 2010). Schools were one of the primary ways in which to inculcate the values and language of society and a common culture and became important as trade spread across the vast empire. At first, schools were basic literacy centers, but they soon expanded their contents and included basic Islamic sciences and the moral values in addition to reading and writing Qur'an as well as Persian (Caferoglu, 1970).

After primary school, students often attended a madrassa, which offered a higher level of education. Most religious people, educators, scientists, and officials who received their education at a madrassa ("a kind of school where courses on different branches of science and literature beside courses on religion and the Arabic language to teach Islam were heavily taught") (Ihsanoglu \& Al-Hassani, 2004, p. 23) learned to speak two languages fluently Turkish and Arabic (Demircan, 1988, p. 18). Most people spoke Turkish, and Arabs learned Turkish as a foreign language. Divanu Lûgat-it Türk, written by Kasgarli Mahmut between 1068-1072 (a 638-page dictionary), was the first book for the Arabs to learn Turkish (Atalay, 1939; Caferoglu, 1970). This book indicates that Turkish was generally learned through the audio-lingual approach among the Turkish language speakers at madrassas (Demircan, 1988).

Education in secular schools among the elite was in French after 1773. During this period, foreigners did not encounter any obstacles or legal regulations in terms of choosing the language of instruction in their schools, and, until 1908, minorities had been supported officially in the use of their language (Akyol, 2006). However, in many public schools, French was used as the language of the educated.

Thus, during the Ottoman Empire, Arabic, Farsi (Persian), and Turkish were the dominant languages. Turkish was the official language of the government, Arabic was spoken in the 
Middle East, North Africa, and the Levant, and Persian and French were spoken by the educated elite (Demircan, 1988).

\subsection{From 1923 to the Present}

Under the leadership of Mustafa Kemal Atatürk, the Republic of Turkey was founded in 1923, after the collapse of the 600-year-old Ottoman Empire in the aftermath of World War I (Fazily, 2012). In terms of linguistics, society, economic reforms, and politics, the newly founded republic concentrated on westernizing the country. While trying to incorporate Westernization in all facets of life, the reforms carried the principles of secularism, nationalism, and modernization (Akyol, 2006).

Each minority group before the founding of the Republic of Turkey had been allowed to use its mother tongue or different foreign languages in school environments. During the last days of the Ottoman Empire, in the latter part of the $19^{\text {th }}$ century, the languages of minority groups were taught in Turkish schools (Demircan, 1988). Besides Arabic and Persian, different languages such as Bulgarian, Armenian, Albanian, and Greek were also taught in schools. Turks, during the Ottoman Empire, had been educated in Arabic at madrassas; however, competent devshirme, youths who could speak both Turkish and Arabic, were educated in a foreign language. Some nationalities were educated in their mother tongue. For instance, Rums (Greeks of Turkish nationality) educated their people in Greek, their mother tongue. Until the collapse of the Empire in 1923, some schools continued to educate their students in a foreign language because those who knew languages other than Turkish were needed (Ergin, 1977).

However, this situation changed after the republic was founded. One of the first acts of the government was to standardize language usage. In 1924, the Act of Unification of Education (Tevhid-i Tedrisat Kanunu) was approved in the Turkish parliament, and this combined all educational institutions under the Ministry of Turkish Education and created a national curriculum for schools (Yavuz, 1987). According to the Act of Unification of Education, the teaching of any other language than Turkish in the formal education system was banned in the country. During this period of time, learning a language, particularly a European language such as German, French, and English, is strongly recommended and supported by society and the government. However, according to Icduygu, (2015), encouraging and learning minority languages is not as popular as learning European language groups. The Government in 1932 founded the Turkish Language Association (Türk Dil Kurumu) to standardize the language and to purify the Turkish language of Persian and Arabic words. This standardization was rapidly applied to public schools during this period. Henceforth, the government permitted only Turkish to be the national language used in all public schools (Ozden, 2013).

However, all schools and universities could teach foreign language courses and some schools, such as Galatasary High School and Robert College (both in Istanbul), taught mathematics and science courses in a foreign language (Demircan, 1988). Various other universities used English and German as media of instruction in concert with learning the cultural, military, political, and commercial affairs with other nations. Between the years of 1933 and 1953 Istanbul University became famous, using English and German. Ankara University used 
German as the medium of instruction in some departments such as History, Geography, Faculty of Language, and Agriculture. To train foreign language teachers, the government founded foreign language departments at universities (Widmann, 1981; Yavuz, 1987). Some schools, such as the Turkish Educational Association, Ankara College (founded in the 1930s) have used English as the medium of instruction for all courses excluding cultural ones so that students would learn of other modern civilizations.

Currently, Turkey hosts the largest number of refugees in the world (Fazily, 2012; Ozden, 2013). More than three million Syrian refugees are in Turkey, and the school-aged Syrian refugee children population reached 1 million in Turkey by the end of 2016 (O'Hanlon, 2017). To address the urgent humanitarian needs of Syrian refugees and to enable them to gain access to the labor market, "Turkey has created a strong asylum framework through the Law on Foreigners and International Protection and the Temporary Protection Regulation" (Kabasakal \& Bodur, 2002, p. 45).

However, most Syrian refugees currently cannot access the labor market because they speak Arabic (Kaya, 2015). In Turkey, nearly 400,000 of an estimated 663,1382 Syrian refugee children (aged 7-18) do not attend school because many of them need language training (Kadizade, 2015). A lack of funding for teacher salaries, a lack of school facilities, limited teacher capacity, distance from schools, economic vulnerability and financial needs are huge obstacles for the educational participation of Syrians in Turkey (Icduygu, 2015). Poor Turkish language ability creates serious challenges for students in public schools. Therefore, a bilingual education program might be a remedy for both Syrians and all other Arab communities in Turkey to increase access to educational services and enhance the quality of provisions.

\section{Historical Background of Kurdish Language in Turkey}

\subsection{From Ottoman Empire to 1923}

Kurds are one of the ethnic groups that are different from the Arabs and the Turks, and they were provided with "de facto autonomy" in the Ottoman Empire's eastern region (Akyol, 2006). Because of the Empire's dispersed structure, the Ottoman government was not a hindrance to the Kurdish people's tribal structure; therefore, the Kurdish people stayed loyal to their traditions and system. Kirisci and Winrow (1997) affirmed that, "in the late nineteenth century within the Ottoman Empire, the typical Arab, Albanian or Turk was not aware of their separate ethnic identity. Likewise, the Kurds were not ethnically self-conscious. The population of the Ottoman Empire rather identified themselves on religious grounds" ( $\mathrm{p}$. 22).

Early on, the Kurds had various publications that promoted their cause. The Bedirhan family, prominent members of the Kurdish community, founded the Kurds' first daily newspaper (Kurdistan) that first appeared 1898 and was published in Cairo, Egypt, and Geneva, Switzerland. This newspaper served as a conduit for the dissemination of Kurdish nationalistic and cultural activities (Akyol, 2006). In the 1900s, written Kurdish literature and culture flourished. According to Hanioglu (2001), Șerif Pasha of Suleymaniyeh, an Ottoman 
diplomat, and the Bedirhans designed an educational society and numerous literary clubs in Kurdish in 1908. Kurdish children were educated in the Kurdish school in Istanbul until the authorities closed it in 1909 (Kinnane, 1964). Other centers of the Kurdish language and culture were found in Diyarbakırin southeastern Turkey and Baghdad and Mosul, both in modern day Iraq.

Within the Ottoman Empire, Kurds, Turks, Arabs, and Circassians had a very close relationship. As understood, the Ottoman Empire was a generally united group of individuals incorporating many different of languages and cultures, widening at numerous eras from Yemen to Hungary and Southern Poland to what is today from Algeria to the Caspian Sea (Polat, 2007). The Kurdish people were especially active in the eastern territory of the Ottoman Empire. McDowall (1996) noted that:

The Kurds provided substantial manpower for the Ottoman army. Thousands of Kurdish conscripts perished with the Third Army at Sarikamish [a battle between the Russian and Ottoman empires during World War wherein the Ottoman Army incurred over 100,000 casualties], and on other fronts. Naturally, there was an almost universal reluctance to serve in the regular army, but even so, many were enrolled and the greater part of the Ottoman forces in the region was Kurdish (p. 105).

Many Kurdish leaders within the Turkish territory personally knew Mustafa Kemal Atatürk, the founder of modern Turkey. He had made many friends among the chieftains and led them to trust his friendship regarding the Kurdish people (Bruinessen, 1993). Mustafa Kemal had asked important well-known Kurdish people, even Kurdish nationalists, to come to the Sivas Congress in September of 1919 and Erzurum Congress in July and August of 1919. He guaranteed that in an independent Turkey, Turks and Kurds would have equal rights (Akyol, 2006). The Kurdish people, according to Akyol (2006), were represented proportionally in the Grand National Assembly in 1920, and several Kurdish people were appointed to serve in the first Representative Committee (Heyet-i Temsiliye).

From 1919 through 1921, Mustafa Kemal Pasha had a very strong friendship with Kurdish chieftains. In September 1919, he highlighted the idea of unity and gave a brotherhood messages as follows.

As long as there are fine people with honor and respect, Turks and Kurds will continue to live together as brothers around the institution of the Caliphate, and an unshakeable iron tower will be raised against internal and external enemies (McDowall, 1996, p. 187).

Ziya Gokalp, a famous Turkish sociologist, writer, poet, and political activist, worked on a study entitled Inquiries Regarding Kurdish Tribes (Kürt Așiretleri Hakkında Tetkikler) and presented it to the government in Ankara (capital city of Turkey). His work in 1922 highlighted the values of both the Turkish and Kurdish communities, their common viewpoints, and the unity of their history. In his study, he stated that:

The fact that both Turks and Kurds gave the same significance and value to our Milli Misak (National Borders) shows that the faithful connection and loyal attachment between both communities is sincere beyond imagination. As a matter of fact, our 
Country has not suffered from the Kurds since Meşrutiyet (Constitutional Monarchy). Is it not a fact that these faithful people have given us a friendly hand and shared our sorrows during our most catastrophic days, such as the Balkan Wars and Armistice? Is not it true that same loyal people are now taking part in the Liberation Struggle with all of its ranks, and shouting "all or nothing" together with the Turkish people? ... Such historical examples show that Turks and Kurds are friends who always fought with faith to protect our special land from the enemy and our holy religion from any disturbances ( $\mathrm{p}$. 115).

At the end of his paper, he said that "Turks and Kurds are united both physically and spiritually as they have shared a religion, history and geography for a thousand years," and ended by asserting, "No Turk is a Turk unless he likes Kurds, No Kurd is a Kurd unless he likes Turks" (p. 118). This statement indicated that the Turkish and Kurdish peoples had a strong relationship with each other and that this brotherhood between the Turkish and the Kurdish needed to be protected.

\subsection{From 1923 to $1950 \mathrm{~s}$}

Since 1923, the Kurdish issue and the Kurdish language in particular in Turkey has been one of the most serious internal issues that the country has faced (Polat, 2007; Skutnabb-Kangas \& Bucak, 1994; Ozfidan, 2014; Kendal, 1980). According to Polat (2007), in 1923, the government of the Republic of Turkey's strategy tried to establish a common sense of belonging to one nation and a personal identification under the assumption that Turkey was settled by only one nationality who spoke a single language: Turkish. Therefore, Turkish was deemed to be only formal language. Nevertheless, speaking and learning of languages such as English, German, and French were encouraged and approved of during this period because they were common languages in the world. According to Skutnabb-Kangas and Bucak (1994), Kurds were not able to express and learn their mother tongue in either public areas or in their own home, let alone in schools or in government institutions. The constitution of Turkey contained a written law in 1923 prohibiting the Kurdish language (May, 2001; Skutnabb-Kangas \& Bucak, 1994).

Mahmut Celal Bayar, the Turkish Minister of Economy in 1934, arranged a visit to eastern parts of Turkey, and, after he returned in December, he submitted a report to the prime minister's office to conduct investigations. This report, 70-typed pages in length, included some interesting observations regarding the political situation, but it was generally linked to economic difficulties and problems in the region. Celal Bayar, in this report, indicated that "our" Kurdish citizens inhabited and worked in empty places with their children, and they have "a genius vigor in their lives" (cited in Mazici, 1997, p. 24). Celal Bayar also said:

We should continually work in order to eliminate detrimental aspects of the policy to be externally imposed and connect these citizens to the motherland. As long as these people are formally told that they are foreign elements, what we will have is nothing but a reaction. Today, it seems like these people are prevented from getting education and governmental jobs, for they are Kurds. It would be fair to say that the administrative personnel do not know exactly what system they should follow in relation to these 
citizens. I believe that clear instructions should be given to these personnel in an organized way. This would prevent hesitations and prevent conflicts that may be caused by personal interpretations (cited in Karaca, 1991, p. 66).

One of the most important points that Bayar highlighted was his caution that Kurdish people would "react ... if these people were formally told that they are foreign elements."

Tevfik Rüş̧ü (Saraçoğlu), Turkish Minister of Foreign Affairs in 1931, expressed obviously Social Darwinist tones in following remarks.

As far as the situation of Kurds is concerned, their cultural levels are so low and their mindsets are so underdeveloped that they cannot exist within the Turkish national structure ... As they are not strong in terms of their economy, they will lose the struggle that they have with Turks who are more advanced and intellectual ... Most of them could migrate to Iran or Iraq, the remaining ones will be subject to destruction which is inevitable for the weak in the struggle for life (cited in McDowall, 1996, p. 200).

Alienation became obvious and unavoidable for the Kurds because of the humiliations and forbiddances exhibited by such political attitudes. This estrangement affected not only the Kurdish people, but also other social communities who felt abused and ignored by the system. Within the Kurdish community of the young Turkish Republic, this situation profoundly affected them in a negative way (Nomer, 1996).

\subsection{From 1950s to 1980 s}

In 1950, according to Kendal (1980), using the Kurdish language in everyday private life was officially allowed; however, using the Kurdish language was still forbidden in public. Because of gradually increasing hostile relationships between the political Kurdish movement and the controlling government from the 1960s to the 1990s, great restraint was applied to the Kurdish culture and language. During this period, numerous military coups took place, and the military ruled Turkish politics (May, 2001).

Regarding language rights, Kurdish activists first intended to remove the prohibitions on Kurdish so that their rights, which existed throughout Ottoman Empire before 1923, would be re-established (Skutnabb-Kangas, \& Bucak, 1994). Furthermore, in the previous half-century, after Kurdish people had achieved tolerance rights at several points, they began to maintain their own language to pursue their rights. The goal of these language rights was not merely to gain the freedom and opportunity to write and speak their language, but also the right to receive an education in Kurdish and teach the Kurdish language.

The Kurdish Workers Party (PKK), established in 1978 and labeled a terrorist group, adopted a policy of armed resistance in 1984 to achieve Kurdish rights. The Kurdish language was considered to be a hazard and a threat to the security of the community and the independence and existence of the country (May, 2001). In part this was because all Kurds were considered to be a part of the PKK, a terrorist group (Akyol, 2006). Since then, the PKK has carried out a guerrilla-style war that has continued until today (Koivunen, 2002; Kaya, 2015), and this is seen as a direct threat to the existence of the Republic of Turkey. 


\subsection{From 1980s to the Present}

President Turgut Ozal was elected in 1989 and held office until 1993. His mother was Kurdish, and he was born in a Kurdish region. He intentionally declared the legitimacy of the Kurdish language in 1991 and partly removed prohibitive laws against Kurdish language usage. The new regulations he instituted allowed using the Kurdish language in different environments such as education, publications, television and radio broadcasts (Koivunen, 2002). This respite was short-lived. By the late 1990s, prohibitive laws against Kurdish were again revived under Ozal's successor, Suleyman Demirel, who was elected a month after Ozal's death.

Today, although Kurds inhabit nearly all geographical areas of Turkey, the Kurdish people mostly inhabit the mountainous regions close to Iraq, Syria, and Iran, particularly in the southeastern part of Turkey (Akyol, 2006). Kurdish people mostly live in rural regions in small cities and villages (Polat, 2007). The rural Kurdish economy comprises mostly agricultural pursuits and animal husbandry. They speak Kurdish, part of the Indo-European language family's western Iranian branch. A clear majority of Kurdish people in Turkey are Sunni Muslims; more than $95 \%$ of the entire Turkish population is also Sunni. However, a small number of Kurdish people inhabiting areas in Iraq are Yazidis and a small Kurdish number are Shiite Muslims (Koivunen, 2002).

The school attendance rate is lower in rural regions of Turkey that are predominantly located in the southeastern part of Turkey than in urban regions even though the Turkish public education system provides free elementary, secondary, and high school education (Arslan, 2005). Hence, Kurdish families have the lowest literacy rates in eastern and southeastern Turkey among other cities (Ozfidan \& Ugurlu, 2015). The attendance of girls is even lower than the average in southeastern regions, and the differences between male and female literacy rates, according to the Turkish Statistics Association in 2006, was more than $10 \%$ in Turkey, even though numerous girls are considered literate in recent years (Polat, 2007).

Currently, two perspectives exist for the Kurdish language in Turkey. These are the actual use of language by speakers and the language itself. In various countries, people currently write the Kurdish language in numerous distinctive scripts, comprising Cyrillic, Roman, and Arabic. As a language, the development of Kurdish has been hindered by the fact that the language has been repressed, and native speakers are isolated (Ozfidan, Burlbaw, \& Kuo, 2016). Most Kurdish speakers in Turkey are illiterate in written Kurdish, and many Kurdish language speakers have never seen their written language in its modified Latin script in Turkey, even when publications have been permitted (Kendal, 1980; Hassanpour, 1992; Skutnabb-Kangas \& Bucak, 1994; May, 2001).

In Turkey, the Kurds, in terms of language use, can be placed into three categories even though the Kurdish people themselves cannot clearly describe the current situation of the Kurdish language. The first group comprises the people whose Kurdish is very poor, or who barely know Kurdish, but who believe that they are genealogically Kurdish (Smits \& Gündüz-Hoşgör, 2003). The second group contains people who speak only the Kurdish language - those who have not attended state schools in which all subjects are being taught in 
Turkish, the rural population, or those all mainly representing older men and women (Mutlu, 1996). The third group includes people who can speak both Turkish and Kurdish fluently (Smits \& Gündüz-Hoşgör, 2003). The third group can be divided further into "people who are native bilinguals without equal proficiency levels in both languages and people who only spoke Kurdish till [sic] they commenced formal education in Turkish, beginning around 6 or 7 years of age" (Smits \& Gündüz-Hoşgör, 2003, p. 23). Unfortunately, no estimates currently exist regarding how many speakers fall into each group.

Recently, on June 12, 2012, the Turkish government declared Kurdish to be an elective subject and allowed it to be taught in schools. Recep Tayip Erdogan, Prime Minister of Turkey, stated that,

Kurdish language can be taken as an elective class in Turkey and can be learned and taught. This is a historical step. With this way, citizens who have a different mother language can improve their cultures and languages according to their demands and needs (Albayrak, 2012).

From this point on, lessons in Kurdish language instruction has been available in schools. For Turkey, this was a vital step toward creating a bilingual education program. The Turkish government has taken democratic steps toward developing the rights of Kurdish people; however, some have voiced concern that creating education in Kurdish might cause segregation between different ethnic groups such as the between Turks and the Kurds (Kaya \& Aydin, 2013; Ozfidan \& Burlbaw, 2016). Even though the law has allowed the Kurdish as an elective, there are challenges such as lack of supplies, lack of teachers, lack of training to offer Kurdish in the schools.

\section{Historical Background of Laz Language in Turkey}

One member of the South Caucasian language family is the Laz language. All South Caucasian languages are spoken in the Republic of Georgia except for Laz. Laz is the only language of the Kartvelian family whose ancestral settlement area is mainly located beyond the borders of Georgia (Gunter \& Andrews, 1993). Today, Laz is mostly spoken in Turkey (Kutscher, 2008). Most Laz speakers today live in Findikli (Vitze), Camlihemsin (Vica), Ardesen (Art'aşeni), Pazar (Atina), Sarp (Sarpi), Hopa (Xopa), Arhavi (Ark'abi), Ikizdere (Xuras), and Borcka (Borçxa) from far northeastern Turkey near the Black Sea. After the 1877-1878 Russo-Turkish War, Laz also lived in northwestern Turkey settling in Golcuk, Karamursel, Sapanca, Akcakoca, Yalova, and Bartin. Within a historical framework, the Laz people have mostly associated with the Turkish culture and have indicated their loyalty to that culture (Serdar, 2013).

Most Laz people (approximate population of 1.5 million) are competent speakers of the Turkish language, and members of older generations (primarily those older than 35 years of age) are also proficient in Laz language. Many Laz people, especially the younger generation, however, are fluent in Turkish only. Furthermore, native Laz speakers mostly confine using their language to communication among family members or friends because the political attitudes in Turkey have created linguistic alienation by means of humiliation and 
forbiddances (Gunter \& Andrews, 1993). Laz has several dialectal varieties and no spoken or written standard form.

The Laz language as spoken in northeast Turkey is now an endangered and under described language (Lacroix, 2009). They did not have a common writing system until 1920s. Iskender Tzitaşi prepared the first Laz alphabet of Latin origin in the Union of Soviet Socialist Republics. In 1984, Lazoglu and Feurstein developed a writing system based on the Turkish alphabet. Although Laz intellectuals have made some effort to establish Laz as a written language based on this system, most Laz use their language in oral communication only (Kutscher, 2008).

Although native folklorist Tsitas created an alphabet and published several works in the 1920s, the written language remained mostly dormant because of limited resources and documentation. Not until Lazoglu and Feurstein released the Lazuri Alboni (Laz Alphabet) in 1984 was the written language resurrected. Lazebura, which is the name of a magazine and now a website, published this alphabet for Laz people who live in Germany. Currently, the written language has two alphabets: the Mkhedruli (Georgian) alphabet for Laz community who inhabit in Georgia, and the Latin alphabet for Laz community who inhabit Turkey (Gunter \& Andrews, 1993).

The Laz language did not have many standard writings in Turkey because the language did not have official status. However, after the appearance of the alphabet created by Lazoglu and Feurstein in 1984, which was based on the Turkish language system, publications began to appear (Kutscher, 2008). In most Laz language publications, the Lazoglu and Feurstein system has been used because most Laz speakers live in Turkey in which the Latin alphabet is used. Using both the Georgian and Latin alphabets, a textbook named Nana-nena (mother tongue) was first published in 1991 (Kutscher, 2008). Later, Bucaklişi and Uzunhasanoğlu created the first Laz-Turkish dictionary, Didi Lazuri Nenapula and released the book to the market in 1999 (Sarigil, 2012).

In the early $16^{\text {th }}$ century, the speaking of the Laz language was prohibited by the Ottomans in public places including governmental sites and schools (Cagaptay, 2006). In 1930, the Turkish government banned the Laz newspaper Mç'ita Muruntskhi (Red Cross) (Cagaptay, 2006).

Speaking Laz was also forbidden from 1980 to 1991 because this was seen as a political threat to Turkish unity. During this period, some academicians did not accept the existence of the Laz ethnic group (Hann \& Bellér-Hann, 2000). Because speaking Laz was banned in public, many children were unable to communicate with their parents and lost their mother tongue. Most Laz people have a heavy Turkish accent because they did not have any environment to practice their mother tongue (Serdar, 2013).

Many Laz parents hope that their children will have good career prospects and thus place an emphasis on the necessity of a good education (Cagaptay, 2006). Because possessing competent Turkish skills was necessary for a good education in Turkey, Laz parents encouraged their children to learn Turkish instead of Laz. Many parents believed that rearing 
their children to be bilingual would prevent them from becoming proficient Turkish speakers. Because of this, many parents prefer to speak only Turkish with their children. Up until the late 1990s, laws oppressed any usage of minority languages such as Kurdish or Laz in Turkey (Haig, 2001). In addition, many minority groups encountered repressive political factors such as the law enacted in 1934 concerning the naming of children, in which people were forced to choose only Turkish names. The government also decreed in the 1950 s that towns and villages should be renamed.

The effects of hostile Turkish language legislation on minority languages and their implementation regarding the Laz language remain noticeable in the $21^{\text {st }}$ century (Kutscher, 2008). As a result, a diglossic situation can be found regarding issues such as politics, religion, science, and education. The entire communication regarding the public sphere is restricted to Turkish. As far as the semi-public sphere is concerned (e.g., streets and shops), Turkish is mainly used. Among the rural population, town inhabitants mostly spoke Laz in the private sphere but even speaking Laz in private spheres has begun to occur much less frequently.

This practice sometimes leads to a language loss within one generation, and this situation is the product of two different scenarios (Kutscher, 2008). One possible and frequent scenario is the relocation of the family; the elder siblings were reared mainly in a rural environment while the younger ones grow up in a more urban region. A second possible scenario occurs when some siblings visit relatives in a rural region on a regular basis (e.g., during the summer holidays, etc.) while others prefer to stay in town with their parents (Kutscher, 2008).

Since the 1990s, a slight change in the linguistic domains of Laz has been observed; this extends especially to the electronic media but also includes the print media (Kutscher, 2008). Some Laz intellectuals - even though many of them live outside the Laz areas - created a Turkish-Laz magazine entitled Ogni sJcani nena (Listen to your language) (Lacroix, 2009). Unfortunately, publication of the magazine had to be abandoned shortly after its establishment (six issues were published). A few years later a second but equally unsuccessful attempt was made under the name of Mjorä (Gunter \& Andrews, 1993). Additionally, some poetry volumes were published in Laz, and traditional as well as modern Laz music was recorded (e.g., the rock band Lazuri Berepe (Laz sons). Birol Topaloglu, who combines traditional music with pop elements, is not only known among the Laz but also among the Turkish. Since the beginning of the 21 st Century, regional radio and TV channels have become more widespread in the Laz areas (for example, Gelisim-TV in Ardeçen) (Gunter \& Andrews, 1993). They produce programs mainly in Turkish but Laz is spoken occasionally in some programs. Furthermore, some first attempts to maintain the language have been made including the compilation of two Turkish-Laz dictionaries and one grammar book (Cagaptay, 2006).

Every society in the world has its own unique way of dealing with endangered languages to keep them alive by means of revitalization work (Sarigil, 2012). Laz revitalization in Turkey within a language context, according to Kaya (2015), has been endeavored through numerous approaches, such as publishing newspapers or books of world classic status in the Laz language, bringing the mother tongue into schools as an elective course, "using music as a 
medium of transferring heritage language to the next generation and making other people be aware of their unique identities, holding festivals at international level to raise worldwide awareness through governmental help," among other ways (p. 34). All these efforts have the effect of increasing language maintenance and awareness of endangered languages by means of documentation to help a community to conserve its language.

Currently, no university has been established to prepare teachers for Laz or other minority languages language courses (Kaya, 2009). Teachers who know Laz but did not have any experience with it have taught Laz courses as an elective (Kyriakou \& Kaya, 2011). The Laz Institute, founded in 1993, runs a Laz language certificate course, and has held discussions with the Turkish Ministry of National Education (MoNE) to help people become experts and teach Laz as an elective (Kaya, 2009). Nonetheless, in practice, according to Kaya (2015), when students choose an elective course in Laz, the administration in many schools tries to persuade them to change their minds by claiming that the school cannot find a teacher or that an insufficient number of students will enroll the course. As one Non-Governmental Organization working on the subject of the Laz language has noted "local education authorities advise students and their families not to choose the Living Languages and Dialects elective language courses" (Kaya, 2015, p. 75).

No established Laz Language and Literature Department currently exists in any university in Turkey (Kaya, 2009). An application to establish a Laz Language Department was rejected for the Institute of Social Sciences at Recep Tayyip Erdogan University. As justification of this rejection, the university stated that "the Laz language has no historical texts of literary quality that could be the subject of academic research" (Kaya, 2015, p. 34). To open a Laz language department at Düzce University, Laz Institute administrators applied to the university, and they together moved forward in an affirmative way; however, a Laz language department has not been yet established due to bureaucratic and technical obstacles (Kaya, 2015). Laz Institute administrators reported that the reason they were given was the lack of academicians to work in this institution; they were also told that there is no way to find such qualified staff in Turkey (Kaya, 2015). An agreement in 2014 was signed between the Laz Institute and the Ministry of National Education (MoNE) about the preparation of textbooks for Laz elective courses, and they together prepared the textbooks for classes. The Laz Institute has continued to work on preparing textbooks for classes for each grade (Kaya, 2015).

\section{Conclusion}

Laz, Kurdish, and Arabic were started at schools as elective courses, but few, if any, textbooks written in these languages exist (Kaya, 2015). Even textbooks that exist do not mention any of these minority groups; therefore, the existing materials do not reflect the presence of social diversity in Turkey (Kyriakou \& Kaya, 2011).

However, some steps forward have been taken. For example, the Ministry of Education in Turkey has started elective courses in the Circassian languages of Adyghe and Abaza, and the Kurmanji and Zaza dialects of Kurdish (Serdar, 2013). They added Laz in these language groups in the 2013-2014 academic year and Georgian in 2014-2015. Attendance in the Laz 
course in 2013 was 100, and this number rose to 274 in 2014 (Kaya, 2015). However, because of the lack of teachers and materials, the enrolment in these courses is not increasing rapidly.

Preparation for these subjects was not enough to meet the state requirements to train and assign teachers to teach elective courses in state and private schools. For instance, the Department of Kurdish Language and Culture at Mardin Artuklu University in Mardin trained qualified educators to teach Kurdish courses; however, only 27 of the 1000 teachers who graduated from the department were appointed to positions (Kaya, 2015). Therefore, an obvious paradox exists in that many students who register for an elective in Kurdish are being told that the course will not open because of lack of teachers, while hundreds of teachers wait to be appointed to teach these classes. Institutes and Non-Governmental Organizations have taken up the responsibility to prepare course materials for these electives because of the lack of a budget provided by the Ministry of Education in Turkey (Kaya, 2015). For example, the Department of Kurdish Language and Culture at Mardin Artuklu University prepared materials for the Kurmanji and Zaza courses (Kaya \& Aydin, 2013; Aydin \& Ozfidan, 2014).

The Ministry of Education in Turkey has not been provided a budget to prepare textbooks and materials; therefore, some organizations have helped prepare materials for the Ministry of Education (Sarigil, 2012). For each textbook, these organizations paid $600 \mathrm{TL}$ to the Department of Kurdish Language and Culture at Mardin Artuklu University. This department edited, typeset, and designed the textbooks (Kaya, 2015). Likewise, the Ministry of Education in Turkey did not provide a budget to prepare course materials for Laz and Arabic (Kaya, 2015).

Millions of minority people in Turkey whose native language is not Turkish have a problem in receiving an equal education (May, 2001). Most of these minorities are from the Kurdish community; however, the number of minority people from other communities such as the Circassian, Laz, Arab, and Syriac is also gradually increasing. The main argument against demands for mother tongue education is that it would prevent the learning of the Turkish language for minority groups. In other words, if they learn their mother tongue, they might not want to learn Turkish. However, a learning mother tongue does not prevent learning another language or does not cause the loss of a language (Cummins, 2001).

Some universities have established Georgian and Kurdish Language and Literature departments. The Faculty of Arts and Sciences at Düzce University, in northwestern Turkey between Ankara and Istanbul, in the 2013-2014 academic year opened the Circassian Language and Literature department, which provided education programs for the Adyghe language (Kaya, 2015). These departments were opened within the faculties of arts and sciences and not in the faculties of education; therefore, after graduation students needed to be trained to work as a teacher in a separate pedagogical training program (Kaya, 2015).

With the aim of carrying out joint advocacy work, plans are in progress today to establish a Mother Tongue and Education Network. Some NGOs institutions work in the field of the right to education, and they work on projects that include adding minority languages to the curriculum and founding research centers at universities to work on minority languages such 
as Adyghe, Abaza, Arabic, Armenian, Homshetsi, Greek, Laz, Syriac, and Kurdish (Kaya, 2015). The joint work of these institutions helps all minority groups to receive their mother tongue and protects the right of their languages in Turkey (Serdar, 2013). They also indicate that the protection of minority languages is crucial for future generations of these minority groups.

\section{References}

Akyol, M. (2006). The origin of Turkey's Kurdish question: An outcome of the breakdown of the Ottoman ancien régime (Unpublished MA thesis). Bogazici University, Istanbul, Turkey.

Albayrak, A. (2012). Turkey to allow Kurdish elective classes. Retrieved from http://blogs.wsj.com/emergingeurope/2012/06/12/turkey-to-allow-kurdish- elective-classes

Anderson, C. (2009). Kurds in Turkey: Building reconciliation and local administrations. The Beyond Intractability Project, The Conflict Information Consortium, University of Colorado.

Arslan C. (2005). Egitimde reform (Reform in Education). Ankara: Ankara University, Institute of Educational Sciences Publications.

Atalay, B. (1939). Divan'ü Lûgat-it-Türk. Ankara: TDK Yayinlari.

Aydin, H. (2012). Multicultural curriculum development in Turkey. Mediterranean Journal of Social Sciences, 3(3), 277-286.

Aydin, H., \& Ozfidan, B. (2014). Perceptions on mother tongue based multicultural and bilingual education in Turkey. Multicultural Education Review (MER), 6(1), 51-78

Bruinessen, M. V. (1993). Kurdistan Uzerine Yazllar [Writings about Kurdistan]. Istanbul: Iletisim Yayınları.

Caferoglu, A. (1970). In Y. Fak (Ed.), Turk Dili Tarihi [History of Turkish Language]. (No. 3101).

Cagaptay, S. (2006). Islam, secularism and nationalism in modern Turkey: Who is a Turk? New York: Routledge.

Cummins, J. (2001). Bilingual children's mother tongue: Why is it important for education. Sprogforum, 7(19), 15-20.

Demircan, O. (1988). Dunden Bugune Turkiye'de Yabanci Dil: Arapca, Farsca, Fransizca, Ingilizce, Almanca, Latince, Italyanca dillerinin ögretimi ve Turkce'nin bu diller karsisindaki durumu. Istanbul: Remzi Kitabevi.

Demirekin, M., \& Evat, Y. (2013). The problem of equivalence in teaching Turkish as a foreign language on the level of words and word groups. Paper presented at the 6th International Turk Instruction Congress, Niğde, July 2013.

Ergin, O. N. (1977). Turkiye Maarif Tarihi. 1-5 cilt. Istanbul. Retrieved from http://ulkukitap.blogspot.com/2014/09/turk-maarif-tarihi-1-5-cilt.html 


\section{Macrothink

Fazily, F. (2012). The perception of teachers and refugee parents regarding refugee children's education: A parent involvement study (Unpublished doctoral dissertation). St. John Fisher College, Rochester, New York. Retrieved from http://fisherpub.sjfc.edu/cgi/viewcontent.cgi? article $=1023 \&$ context $=$ education_etd

Gokalp, Z. (1922). Kurt Asiretleri Hakkında Sosyolojik Tetkikler (Sociological investigations about Kurdish tribes). Istanbul: Sosyal Yayınlar.

Gokce, F., \& Oguz, N. (2010). Minority and foreign schools on the Ottoman education system. E-International Journal of Educational Research, 1(1), 42-57.

Gunter, M. M., \& Andrews, P. A. (1993). Ethnic groups in the Republic of Turkey. Wiesbaden, Germany: Reichart.

Haig, G. (2001). Linguistic diffusion in present-day East Anatolia: From top to bottom. In L. Behzai, P. Franke, G. Haig, C. Herzog, B. Hoffmann, L. Korn, \& S. Talabaron (Eds.), Bamberger orientstudien (Vol. 1, pp. 195-224). Bamberg, Germany: University of Bamberg Press.

Hanioglu, S. (2001). Preparation for a revolution: The Young Turks, 1902-1908. NewYork: Oxford University Press.

Hann, C., \& Bellér-Hann, I. (2000). Turkish region: State, market \& social identities on the east Black Sea coast. Oxford: Currey.

Hassanpour, A. (1992). Nationalism and language in Kurdistan, 1918-1985. San Francisco: Mellen Research University Press.

Hourani, A. 1970). Arabic thought in the liberal age, 1798-1939. Oxford: Oxford University Press.

Icduygu, A. (2015). Syrian refugees in Turkey: The long road ahead. Washington, DC: Transatlantic Council of Migration, a Project of the Migration Policy Institute. Retrieved from https://www.scribd.com/document/263865431/Syrian-Refugees-in-Turkey-The-LongRoad-Ahead

Ihsanoglu, E., \& Al-Hassani, S. (2004). The Madrasas of the Ottoman Empire. Foundation for Science, Technology and Civilisation, Manchester. Mathematics Education in the Balkan Societies Up To the WWI.

Itzkowitz, N. (1972). Ottoman Empire and Islamic tradition. New York: Alfred A. Knopf, Inc.

Kabasakal, H., \& Bodur, M. (2002). Arabic cluster: A bridge between East and West. Journal of World Business, 37(1), 40-54. https://doi.org/10.1016/S1090-9516(01)00073-6

Kadizade, E. D. (2015). Identifying accurate equivalents between Turkish and Arabic for foreign language teaching. Educational Research and Reviews, 10(4), 501. https://doi.org/ 10.5897/ERR2014.2024 
Karaca, E. (1991). A $\breve{g r l ~ e t e k l e r i n d e k i ~ a t e s ̧ . ~ I ̇ s t a n b u l: ~ A l a n ~ Y a y ı n c ı l ı k . ~}$

Kaya, I., \& Aydin, H. (2013). Challenges, experiences, and model recommendations for bilingual education. Istanbul: UKAM Press.

Kaya, N. (2009). Forgotten or assimilated? Minorities in the education system of Turkey. London: Minority Rights Group International.

Kaya, N. (2015). Teaching in and studying minority languages in Turkey: A brief overview of current issues and minority schools. European Yearbook of Minority Issues Online, 12(1), 315-338. https://doi.org/10.1163/9789004306134_013

Kendal, N. (1980). The Kurds under the Ottoman Empire. In G. Chaliand (Ed.), People without a country: The Kurds and Kurdistan (pp. 47-106). London: Zed Books Ltd.

Kinnane, D. (1964). The Kurds and Kurdistan. London: Oxford University Press.

Kirisci, K., \& Winrow, G. M. (1997). The Kurdish question and Turkey: An example of a trans-state ethnic conflict. Portland, Oregon: Frank Cass Publishers.

Koivunen, K. (2002). The invisible war in North Kurdistan (Unpublished Ph.D. Dissertation). The University of Helsinki, Helsinki, Finland. Retrieved from http://ethesis.helsinki.fi/ julkaisut/val/sospo/vk/koivunen/theinvis.pdf

Kutscher, S. (2008). The language of the Laz in Turkey: Contact-induced change or gradual language loss. Turkish Languages, 12, 82-102.

Kyriakou, N., \& Kaya, N. (2011). Minority rights: Solutions to the Cyprus conflict. London: Minority Rights Group International.

Lacroix, R. (2009). Laz relative clauses in a typological and areal perspective. In P. K. Austin, O. Bond, M. Charette, D. Nathan, \& P. Sells (Eds.), Proceedings of Conference on Language Documentation and Linguistic Theory 2 (pp. 205-210). London: SOAS.

May, S. (2001). Language and minority rights: Ethnicity, nationalism, and the politics of language. New York: Longman.

Mazici, N. (1997). Celäl Bayar: Basbakanlık dönemi [Period of Prime Minister Celal Bayar] (1937-1939). Istanbul: Der Yayınları.

McDowall, D. (1996). A modern history of the Kurds. London: I. B. Tauris.

Mutlu, S. (1996). Ethnic Kurds in Turkey: A demographic study. International Journal of Middle East Studies, 28(4), 517-541. https://doi.org/10.1017/S0020743800063819

National Legislative Bodies. (2016). Constitution of the Republic of Turkey. Retrieved from http://www.refworld.org/docid/3ae6b5be0.html

Nomer, K. (1996). Şeriat, hilâfet, cumhuriyet, laiklik: dinîve tarihîgerçeklerin belgeleri (No. 206). Istanbul: Bogazici Yayinlari.

O’Hanlon, M. E. (Ed.). (2017). Brookings big ideas for America. Washington, DC: Brookings 
Institution Press.

Ozden, S. (2013). Syrian refugees in Turkey. Florence, Italy: Migration Policy Center. Retrieved from http://www.migrationpolicycentre.eu/docs/MPC-RR-2013-05.pdf

Ozfidan, B. (2014). The Basque bilingual education system: A model for a Kurdish bilingual education system in Turkey. Journal of Language Teaching and Research, 5(2), 382-390. https://doi.org/10.4304/j1tr.5.2.382-390

Ozfidan, B., \& Burlbaw, L. M. (2016). Perceptions of Bilingual Education Model in Spain: How to Implement a Bilingual Education Model in Turkey. Journal of Ethnic and Cultural Studies, 3(1), 49-58.

Ozfidan, B., \& Ugurlu, O. (2015). The Idea of Race And Racial Differences. Electronic International Journal of Education, Arts, and Science, 1(1), 85-98.

Ozfidan, B., Burlbaw, L., \& Kuo, L. J. (2016). Perceptions of an Anticipated Bilingual Education Program in Turkey. International Education Studies, 9(10), 174. https://doi.org/ 10.5539/ies.v9n10p174

Polat, N. (2007). Socio-psychological factors in the attainment of L2 native-like accent of Kurdish origin young people learning Turkish in Turkey (Unpublished doctoral dissertation). The University of Texas at Austin, Austin, Texas. Retrieved from https://repositories.lib.utexas.edu/bitstream/handle/2152/3145/polatd86012.pdf? sequence $=2 \&$ isAllowed $=\mathrm{y}$

Sarigil, Z. (2012). Ethnic groups at 'critical junctures': The Laz vs. Kurds. Middle Eastern Studies, 48(2), 269-286. https://doi.org/10.1080/00263206.2011.652778

Serdar, A. (2013). Ethnic languages, multiculturalism and assimilation. Paper presented at the meeting of 7th Global Conference: Multiculturalism, Conflict and Belonging. Oxford, United Kingdom.

Skutnabb-Kangas, T. (2000). Linguistic genocide in education-or worldwide diversity and human rights? Mahwah, NJ: Lawrence Erlbaum Associates.

Skutnabb-Kangas, T., \& Bucak, S. (1994). Killing a mother tongue: How the Kurds are deprived of linguistic human rights. In T. Skutnabb-Kangas \& R. Phillipson (Eds.), Linguistic human rights: Overcoming linguistic discrimination (pp. 347-370). Berlin: Mouton de Gruyter.

Smits, J., \& Gündüz-Hoşgör, A. (2003). Linguistic capital: Language as a socio-economic resource among Kurdish and Arabic women in Turkey. Ethnic and Racial Studies, 26(5), 829-853. https://doi.org/10.1080/0141987032000109050

Ucarlar, N. (2009). Between majority power and minority resistance: Kurdish linguistic rights in Turkey. Lund University, Lund, Sweden. Retrieved from https://ucris.lub.lu.se/ ws/files/4283150/1486821.pdf

Urla, J. (2009). Ethnic protest and social planning: A look at Basque language revival. 
Cultural Anthropology, 3(4), 379-394. https://doi.org/10.1525/can.1988.3.4.02a00030

Widmann, H. (1981). Atatürk Üniversite Reformu. In A. Kazancigil \& S. Bozkurt (Trans.), I.Ü. Cerrahpasa Tip Fakültesi 100. yil Kutlama Yayini Özel Seri: 3. Retrieved from http://www.osym.gov.tr

Yavuz, H. (1987). Kültür Üzerine. Istanbul: Baglam Yayinlari.

\section{Copyright Disclaimer}

Copyright for this article is retained by the author(s), with first publication rights granted to the journal.

This is an open-access article distributed under the terms and conditions of the Creative Commons Attribution license (http://creativecommons.org/licenses/by/3.0/). 